\title{
Nutrient Composition of Dandelions and its Potential as Human Food
}

\author{
${ }^{1}$ Abdel E. Ghaly, ${ }^{2}$ Nesreen Mahmoud and ${ }^{1}$ Deepika Dave \\ ${ }^{1}$ Department of Process Engineering and Applied Science, \\ Faculty of Engineering, Dalhousie University, Halifax, Nova Scotia, Canada \\ ${ }^{2}$ Department of Agricultural Engineering, Faculty of Agriculture, Cario University, Gizza, Egypt
}

Received 2012-04-15; Revised 2012-05-27; Accepted 2012-06-10

\begin{abstract}
Two thirds of the world's populations are suffering from protein malnutrition and about 36 million people die every year due to hunger. Expansion of present agriculture practices into marginal land is not expected to solve the problem of increasing the food supply. New methods of feeding the ever increasing world population must be developed. The aim of the study was to evaluate the usefulness of the dandelion leaves as a source of supplemental protein. Protein was extracted from the dandelion leaves by blending them after $\mathrm{pH}$ and moisture adjustment, squeezing the resultant pulp through filter press and coagulating the filtrate with acid and heat. The effects of $\mathrm{pH}$, moisture content, pressure and temperature on the extractability and quality of protein were investigated. A mass balance was performed on dry matter and protein contents during the extraction steps. Proximate analysis was performed on the extracted leaf protein and the amino acid profile of the protein curd was determined. The best results of the protein dissolution during the blending step were obtained at $\mathrm{pH}$ of 8.25 and moisture content of $96 \%$. Firm protein curd with light green chalky color was obtained at $3.5 \mathrm{pH}$ and $80^{\circ} \mathrm{C}$. The protein content of dandelion leaves was $4.70 \%$ while the protein content of the curd was $15.93 \%$ on wet basis and $55.43 \%$ on a dry basis. The best leaf protein could be obtained from the young leaves in good conditions. The results showed that dandelion leaves offer a good source of supplementary protein compared to vegetable and fruits. The amino acid composition of dandelion protein seems to be better than most seed proteins and compares favorably with animal proteins. The protein cake at a $\mathrm{pH}$ of 4 had the keeping quality of cheese. Drying the protein cake did not impair the nutritional value but made it hard, dry and gritty. The non extractable protein remained in the fibre and liquor; both have economic values as feed for ruminants and growth medium for microorganisms, respectively.
\end{abstract}

Keywords: Flirtation, Blending, Dandelions, Extraction, Moisture Content, pH, Protein, Amino Acid, Ash, Coagulation

\section{INTRODUCTION}

It has been estimated that two thirds of the world's population are not receiving sufficient protein in their diet (Ghaly and Alkoik, 2010a). About 36 million people die every year due to hunger or as a result of hunger and approximately $60 \%$ of the 11 million deaths each year among children under the age of 5 are attributed to malnutrition (FAO, 2002; WHO, 2002). Expansion of present agricultural practices into marginal land is not expected to solve the problems of increasing the food supply. New methods of feeding the burgeoning population will have to be developed, particularly methods that will guarantee a renewable protein supply, since in many instances it is the lack of protein and not of calories that is the cause of malnutrition (Ghaly and Alkoik, 2010a; Saunders et al., 2011). The development of new sources of protein such as single cell protein (Tannenbaum and Wang, 1975; Ferrianti and Fiechter, 1983), insect protein (Finke, 2002; Ghaly and Alkoik, 2010b), soybean protein (Mendez, 2002; Bhatia and Green, 2008), fish protein concentrate (Shahidi et al., 1991; Sikka et al., 1979) and leaf protein (Faskin, 1999; Ghaly and Alkoik, 2010a) have made significant contributions toward the alleviation of the protein deficiency. However, there is still an estimated one 
billion people suffering from protein deficiency (Ghaly and Alkoik, 2010a).

The process of photosynthesis is the only non-depletable protein source. Of the twenty amino acids from which human proteins are built, eight must be supplied to man from the leaves of green plants (Maciejewiez-Rys and Hanczankovwski, 1990; Tangka, 2003). Surprisingly, only one percent of the world's edible plants are being used for human food. Ninety five percent of plant food comes only from twenty crops and in many countries, only six are actually exploited (Parrish et al., 1974; Nordeide et al., 1996). Protein from leafy vegetables makes up half of all vegetable proteins in the human diet and contributes as much to the world's total protein as does fish, although it receives much less attention (Faskin, 1999; Tangka, 2003).

There are two factors limiting the nutritional value of plants to monogastric animals: (a) the high amounts of fibre and (b) the indigestibility of the cellulosic cell walls. Normally herbivores assimilate the plant proteins and man consumes the herbivore protein and avoids the cellulose. This detour through the food chain is inefficient as only $2-20 \%$ of the plant protein fed to animals is recoverable as animal protein for human nutrition. The yield would be much greater if it was possible to eliminate the middle process by extracting the plant protein from the indigestible fibre and eating it directly. It has been estimated that the extraction of protein from an area of land slightly larger than 20,000 ha could produce enough high grade protein per year to feed a population of one million. An equal amount of protein would be left in the fibre to feed livestocks and thus converted to meat and milk (Vaisey et al., 1975; Tangka, 2003). The leaf protein is of high quality and adult male would receive about the same amount of balanced protein from equal amounts of leaf protein, meat or milk.

Dandelion, Taraxacum vulgaris (Fig. 1) belongs to the botanical family Compositae which is the characterized by the bearing of many small flowers in a disc (Stewart-Wade et al., 2002). Dandelion was brought to North America as a garden plant by settlers (Solbrig, 1971; Tilford, 1997; Heatherley, 1998). The young leaves were used in salads and as medicine while the flowers were used as a dye in dandelion wine. The dandelion is a long-lived perennial with a widely branched root system that can reach $30 \mathrm{~cm}$ in length and $3 \mathrm{~cm}$ in width. The root serves as a storage organ and is filled with a milk-like fluid that has a high latex content. It is marked with annual growth rings and is surmounted by a spiral shaped crown formed as a result of very short internode (each new leaf is placed with its base very close to the insertion of the previous leaf). When the root is injured or broken near its upper portion, an undifferentiated tissue (the callus) is formed to plug the wound and produces new buds within few days (Solbrig, 1971; Tilford, 1997; Kershaw et al., 2002; Kim and Mendis, 2006). The dandelion is a short day plant (does not bloom where there is more than $12 \mathrm{~h}$ of light) and the blooming process is very rapid in spring and fall (Solbrig, 1971; Heatherley, 1998; Welch, 2007). Each plant produces 192-252 seeds, each with its parachute pappus. Dandelion is one of the few apomictic plants that can reproduce asexually and survive practically anywhere (Tilford, 1997; Kershaw et al., 2002). Fifteen year old dandelions were found (Solbrig, 1971; Welch, 2007).

The objectives of this project were to: (a) extract protein from dandelion leaves (b) determine optimum extraction condition and (c) determine the nutritional value of protein crude.

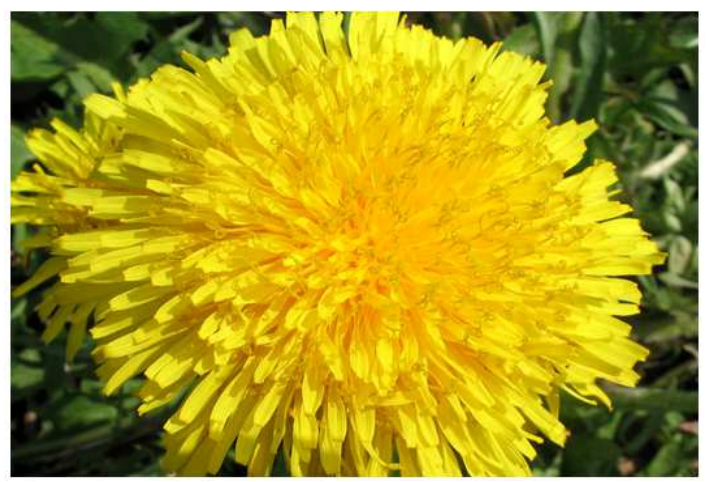

(a)

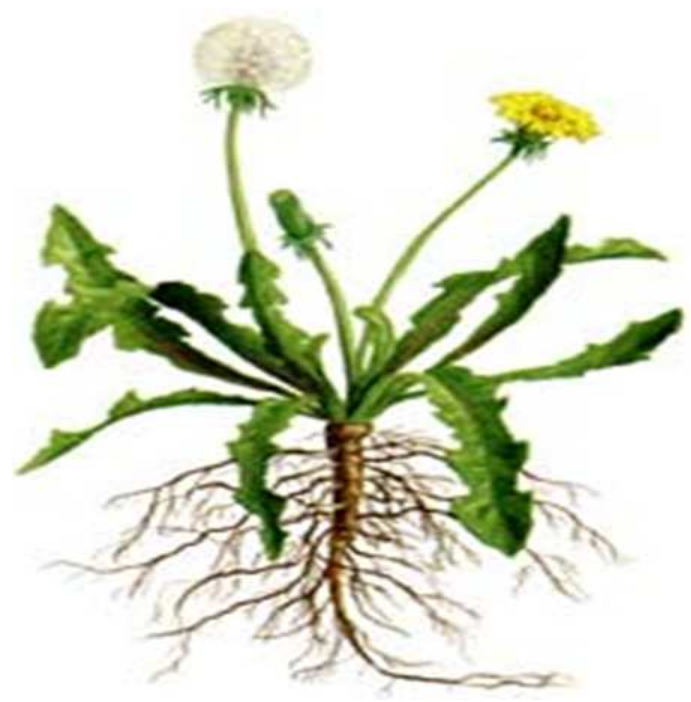

Fig. 1. A rosette-shaped dandelion; (a) Flower; (b) Dandelion plant with flowers and roots 


\section{MATERIALS AND METHODS}

\subsection{Collection of Dandelions}

About $25 \mathrm{~kg}$ of dandelions leaves were gathered from the Citadel and the Common Grounds in Halifax, Nova Scotia between July 15 and September 15, 2008. The leaves were thoroughly mixed, backed in plastics bags and stored at $-15^{\circ} \mathrm{C}$ till needed for the protein extraction process. Twenty samples were selected at random and analyzed for moisture content. The average dry matter content of the leaves was $13.62 \% \pm 1.11 \%$ (moisture content $=86.38 \%$ ).

\subsection{Protein Extraction}

A detail description of the protein extraction process is illustrated in Fig. 2. The moisture and $\mathrm{pH}$ were first adjusted before the pulping process. The blended material was then filtered under vacuum to separate the juice from the cake. The remaining juice in the cake was liberated using a press. The juices from the filtration and press steps were coagulated by heating and acidifying. Then, the mixture was filtered to separate the protein from the liquor.

\subsubsection{Blending}

Leaf protein extractability is influenced by moisture content and $\mathrm{pH}$. Optimum extraction can be achieved at moisture content greater than $95 \%$ and $\mathrm{pH}$ greater than 7.5 . These conditions ensure good flow ability of the leaf slurry and softening of the cell wall. In this study, the $\mathrm{pH}$ was adjusted by adding of $0.1 \mathrm{~N} \mathrm{NaOH}$. Five moisture contents $(95,96,97,98$ and $99 \%)$ were tested. Fifty grams of leaves were placed in a blender (Model V004-43100C, Villa Ware Mfg. Co., Ohio, USA) and $35 \mathrm{~cm}$ of $0.1 \mathrm{~N} \mathrm{NaOH}$ was added to bring the $\mathrm{pH}$ to 8 . The water was then added to bring the moisture content to the desired level. Each sample was blended for $30 \mathrm{sec}$ on "chop" and then for four one-minute periods on blend. Between each blending period, the sides of the glass cylinder of the blender were clean with a spatula, scraping the chopped dandelion leaves down towards the blades.

\subsubsection{Filtration}

Filtration was carried out on the blended samples to separate the librated leaf juice from the pulp. A Bunchner 17 J funnel (Cat. No. 22086769, Fisher Scientific, Ontario, Canada) with Whatman filter papers (\#41, Cat. No. 1441150, Sigma-Aldrich, Ontario, Canada) were used with a $500 \mathrm{~mL}$ vacuum flask (Cat. No. 10-181E, Fisher Scientific, Ontario, Canada). The vacuum (3000 psi or $20684.27 \mathrm{kPa}$ ) was applied using a vacuum pump (RV5, Edwards vacuum pump, Linde Canada Ltd., Ontario, Canada). The blended leave material was poured into the funnel and the amount of juice passing through the filter was measured every $2 \mathrm{~min}$ for the first $20 \mathrm{~min}$ and then every $10 \mathrm{~min}$ for the next $40 \mathrm{~min}$. Two trials were carried out for each moisture content studied: one immediately after blending and the other after $15 \mathrm{~min}$ blending.

\subsubsection{Pressing}

The filter cake was pressed using a specimen mount hydraulic press (20-1410-115 SimpliMet $^{\mathbb{R}} 2$ Hydraulic Specimen Mounting Press, Buehler Ltd., Illinois, USA) to liberate the remaining juice in the filter cake. Two layers of filter paper (\#41 Cat. No. 1441150, Sigma-Aldrich, Ontario, Canada) were used over the strained plate and a pressure of $3000 \mathrm{psi}(20684.27 \mathrm{kPa})$ was applied for $15 \mathrm{~min}$ followed by a pressure of $6000 \mathrm{psi}(41368.54 \mathrm{kPa})$ or $5 \mathrm{~min}$.

\subsubsection{Coagulation}

The aim of coagulation was to separate the protein from the filtered juice while maintaining good consistency and a firm curd. The juices from the blending and pressing steps were combined. Fourteen samples of filtrate $(40 \mathrm{~mL}$ each) were acidified to $\mathrm{pHs}$ of 8.5-2.0 (in 0.5 increments) with $1 \mathrm{~N} \mathrm{HCL}$ and heated to $80^{\circ} \mathrm{C}$. The coagulated protein was separated from the liquor by filtration using the Buchner filtration system.

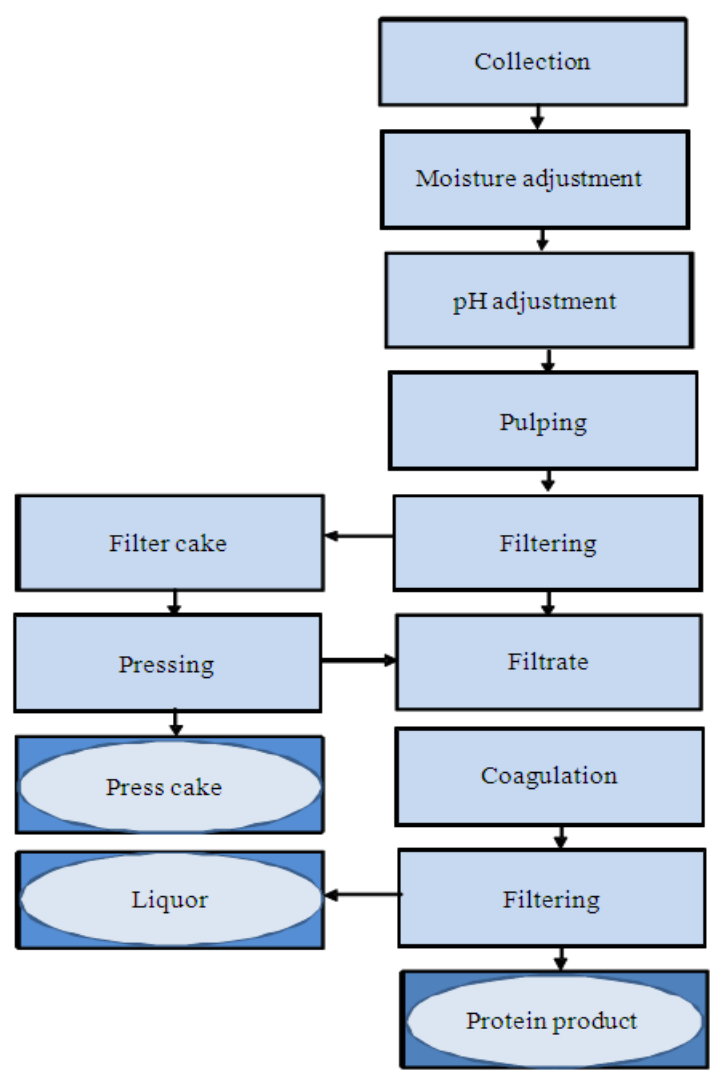

Fig. 2. The extraction process 
The temperatures at which the first cured and first liquor appeared were recorded. The quality and the colour of the cured at $80^{\circ} \mathrm{C}$ were also recorded.

\subsection{Experimental Analyses \\ 2.3.1. Moisture Content}

The oven dry method described in APHA (1990) was followed. The samples were first weighted using a Mettler scientific balance (AE 2005, Mettler Instruments, AG, Greifensee, Zurich, Switzerland). They were then placed in a convection oven (Isotemp oven, Model No. 655F, Fisher Scientific, Montreal, Quebec) for $24 \mathrm{~h}$ at $105^{\circ} \mathrm{C}$. The dried samples were then removed from the oven, left to cool in a dessicator and weighed. The moisture content was calculated as follows:

$$
\mathrm{MC}=\frac{\mathrm{M}_{1}-\mathrm{M}_{2}}{\mathrm{M}_{1}} \times 100
$$

Where:

$\mathrm{MC}=$ The moisture content $(\%)$

$\mathrm{M}_{1}=$ The initial weight of the wet sample (g)

$\mathrm{M}_{2}=$ The weight of the dried sample (g)

\subsubsection{Ash Content}

The ash content was determined gravimetrically on the dried samples according to the procedure described in APHA (1990). The dried samples were placed in a muffle furnace (Isotemp muffle furnace, Model No. 186A, Fisher Scientific, Montreal, Quebec) for $30 \mathrm{~min}$ at $550^{\circ} \mathrm{C}$. They were removed from the muffle furnace, left to cool in a dessicator and then weighed using a Mettler scientific balance (AE 2005, Mettler Instruments, AG, Greifensee, Zurich, Switzerland). The ash content was calculated as follows:

$$
\mathrm{AC}=\frac{\mathrm{M}_{3}}{\mathrm{M}_{2}} \times 100
$$

Where:

$$
\begin{aligned}
& \mathrm{AC}=\text { The ash content }(\%) \\
& M_{3}=\text { The weight of the material remaining after }
\end{aligned}
$$

\subsubsection{Proximate Analysis}

The dandelions tissue analysis (moisture content, protein, fat, carbohydrate and ash) were performed at Maxxam Analysis Inc, Mississauga, Ontario. The analysis was also performed on the dry matter of dandelions.

\subsubsection{Fat Content}

The fat content was determined using the ether extraction technique according to the procedure described in the Official Method of the Association of Official Analytical Chemists (AOAC, International, 2005). Hot ether was percolated through a porous receptacle filled with ground dandelions leaves for $24 \mathrm{~h}$. The fat was released from the dry matter and collected in a flask at the bottom of the apparatus. The receptacle was removed, dried in a vacuum oven (Isotemp oven, Model No. 655F, Fisher Scientific, Montreal, Quebec) for $24 \mathrm{~h}$ at $105^{\circ} \mathrm{C}$ and then reweighed. The change in weight corresponded to the fat content of the original sample. The fat percentage was computed from the following equation:

$\mathrm{FC}=\frac{\mathrm{W}_{\mathrm{f}}}{\mathrm{M}_{\mathrm{s}}} \times 100$

Where:

$\mathrm{FC}=$ The fat content (\%)

$\mathrm{W}_{\mathrm{f}}=$ The weight of fat extracted $(\mathrm{g})$

$\mathrm{W}_{\mathrm{s}}=$ The weight of the dried sample $(\mathrm{g})$

\subsubsection{Protein Content}

The total protein was determined using the Tecator Kjeltec Auto Analyzer (Model-1026, Fisher Scientific, Montreal, Quebec). The ground dandelions leaves were transferred to the macro $250 \mathrm{~mL}$ digestion tubes. One "Kjeltab" (containing $3.5 \mathrm{~g} \mathrm{~K}_{2} \mathrm{SO}_{4}$ and $0.0035 \mathrm{~g} \mathrm{Se}$ ) and $3.0 \mathrm{~mL}$ of distilled water were added to the samples in the digestion tubes. The samples were digested at $420^{\circ} \mathrm{C}$ for $30 \mathrm{~min}$ in a digestion block heater (Tecator Digester System, 20 Model-1016, Fisher Scientific, Montreal, Quebec). The digestion tubes were removed and allowed to cool for $10 \mathrm{~min}$. Then, $30 \mathrm{~mL}$ of distilled water was added to each of the digestion tubes. The digestion tubes were transferred to the Auto Analyzer. The constants A and $\mathrm{B}$ for the equipment were set at 0.00 and 1.862 , respectively. The titrant acid and the predetermined blank sample were set at $0.2127 \mathrm{M}$ and 0.01 , respectively. Distillation, titration and calculation were performed automatically. Similar procedures were used to determine the protein contents of the filter cake, press cake, protein curd and filtrates. The protein percentage was computed from the following equation:

$\mathrm{PC}=\frac{\text { Displayed result }}{\mathrm{W}_{\mathrm{s}}}$ 
Where:

$\mathrm{PC}=$ The protein content $(\%)$

$\mathrm{W}_{\mathrm{s}}=$ The weight of the sample of live dandelions leaves $(\mathrm{g})$

\subsubsection{Amino Acids}

The amino acids (Alanine, arginine, cysteine, glutamic, glycine, histidine, isoleucine, leucine, lysine, methionine, phenylalanine, serine, threonine, trytophan, tyrosine and valine) were determined using the HFB-IBA (Heptafluorobutyric isobutyl esters of amino acids) amino acid derivatization kit (Cat. No. 18094, Altech Associates, Inc., Deerfiled, Illinois, USA). The sample was placed in a small reaction vial. An amount of $3 \mathrm{~mL}$ of $0.2 \mathrm{M} \mathrm{HCl}$ was added to each vial and the solutions were heated to 16500-10, Hach Chemical Co., Loveland, CO) for $30 \mathrm{~h}$. Then, the vials were removed from the heater and dried under stream of dry nitrogen. About $1.25 \mathrm{~mL}$ of acetyl chloride (Cat. No. 18094B, Altech Associates Inc. Deerfield, Illinois, USA) was slowly added to $50 \mathrm{~mL}$ of isobutanol and the mixture was added to each vial (which contained dry sample). The vials were capped and heated at $110^{\circ} \mathrm{C}$ for $45 \mathrm{~min}$. The vials were uncapped and heated at $115^{\circ} \mathrm{C}$ under a stream of nitrogen to remove excess reagent. Then, the vials were removed from the heater and cooled in an ice bath (Precision water bath microprocessor controlled 280 series, Model 284, Cat. No. 1547418, Fisher Scientific, Ottawa, Ontario, Canada) for approximately $5 \mathrm{~min}$. About 3 $\mathrm{mL}$ of methylene chloride and $2 \mathrm{~mL}$ of HFBA, Cat. No. 18094A, Associates Inc. Deerfield, Illinois, USA) were added to each vial. The vials were then capped and heated at $100^{\circ} \mathrm{C}$ for $4 \mathrm{~h}$. The vials were removed form the heater and cooled to ambient temperature. The excess reagent was evaporated under a stream of dry nitrogen. The samples were redissolved by adding $2 \mathrm{~mL}$ of ethyl acetate and injected into the gas chromatograph (Model-HP5890).

\section{RESULTS}

\subsection{Blending}

The results of blending with different moisture content are shown in Table 1. The results showed that the 95\% moisture pulp was too dry and the chopped leaves were thrown from the blades onto the glass. On the other hand, the $99 \%$ moisture pulp was too soupy. The best range of moisture content was $96-98 \%$. The best result was obtained at a moisture content of $96 \%$. However, higher moisture content (98\%) cushioned the leaves so that fewer cells were broken during the pulping process.

\subsection{Filtration}

The juice passed through the filter rapidly at first and then slowed down after a few minutes as shown in Fig. 3. The material that was delayed for $15 \mathrm{~min}$ after blending did not pass easily through the filter. Only $22 \mathrm{~mL}$ of juice were collected after $260 \mathrm{~min}$ compared to $114 \mathrm{~mL}$ in $60 \mathrm{~min}$ for the material that was filtered immediately after blending. This indicated that pulp was aged very quickly.

\subsection{Pressing}

The purpose of pressing was to liberate the juice remaining in the filter cake. Pressing was tried with one, two and three layers of filter. The results indicated that one layer of filter was not strong enough and three layers backed up the juice causing flow by pass through the o-rings. It was also noticed that a pressure of $3000 \mathrm{psi}$ $(20684.27 \mathrm{kPa})$ was adequate to liberate $16.5 \mathrm{~mL}$ of the juice from the filter cake in $10 \mathrm{~min}$. The higher pressure of $6000 \mathrm{psi}(41368.54 \mathrm{kPa})$ liberates another $5 \mathrm{~mL}$ of juice from the filter cake in $1 \mathrm{~min}$ (Fig. 4).

\subsection{Coagulation}

To ensure the accuracy of the acidity of the coagulation process, it was necessary to determine the buffering capacity of the leaf juice. A sample of $120 \mathrm{~mL}$ each of the filtrate was titrated with $1.0 \mathrm{~N} \mathrm{HCl}$. The results showed in Fig. 5 indicated that the $\mathrm{pH}$ of the juice was 8.0 and the juice did not have any buffering capacity. The coagulation results are presented in Table 2. No coagulation was observed at room temperature under all $\mathrm{pH}$ conditions. Only under $\mathrm{pH} 4.5$, a rippling in the dark green juice started at a temperature of $33^{\circ} \mathrm{C}$. At $52^{\circ} \mathrm{C}$, the juice started separating into tea-like liquor from the dark green-brown protein precipitate. The amount of protein coagulated increased with increase in temperature up to $80^{\circ} \mathrm{C}$. The protein curd was most firm at a $\mathrm{pH}$ of 3.5 . Most of the tea-like green liquor passed through the filter in $1 \mathrm{~min}$ and no liquid pressed through after $10 \mathrm{~min}$. The curd had a light green chalky appearance with a $\mathrm{pH}$ of 3.5. The filtered protein was dried at room temperature.

Table 1. Effect of moisture on the quality of pulp

\begin{tabular}{|c|c|c|c|c|}
\hline Moisture content $(\%)$ & Added water $(\mathrm{mL})$ & Added $\mathrm{NaOH}(\mathrm{mL})$ & Final $\mathrm{pH}$ & Observations \\
\hline 86.38 & 0 & 35 & 8.00 & Very dry bulb \\
\hline 95 & 93 & 35 & 8.11 & Dry bulb and many complete cell walls \\
\hline 96 & 127 & 35 & 8.32 & Good cell breakage \\
\hline 97 & 184 & 35 & 8.86 & Some cell breakage and some cell lumps \\
\hline 98 & 297 & 35 & 9.07 & Poor cell breakage and many intact cell lumps \\
\hline 99 & 638 & 35 & 9.31 & Soupy pulp and complete cell wall \\
\hline
\end{tabular}


Abdel E. Ghaly et al. / American Journal of Biochemistry and Biotechnology 8 (2) (2012) 118-127

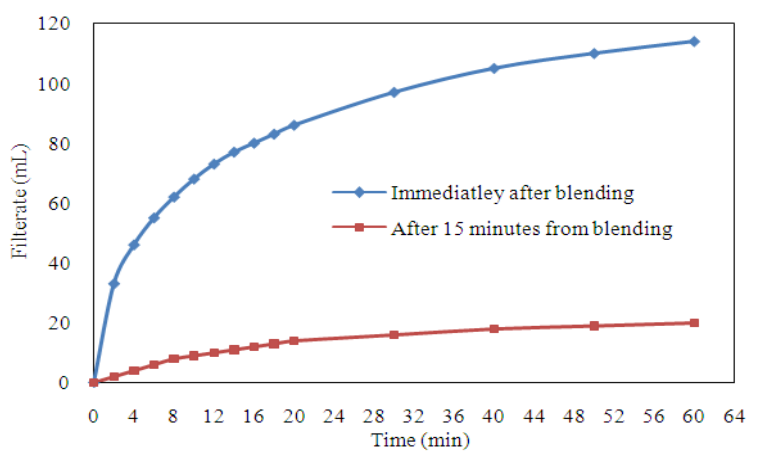

Fig. 3. Liberated juice from filtration immediately after pulping

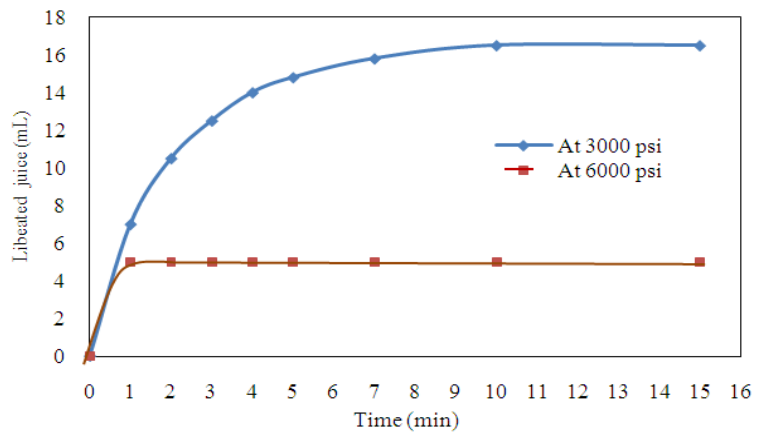

Fig. 4. Librated juice from the pressing

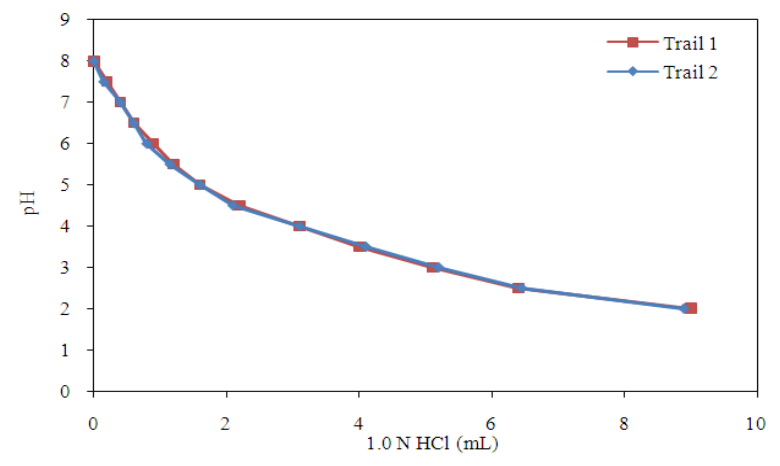

Fig. 5. The buffering capacity of the protein liquor

\subsection{Mass Balance}

The dry matter and protein contents of the various materials were calculated and a mass balance was performed on the entire protein extraction process as shown in Table 3. The final dry matter content of protein curd was $28.74 \%$ with a protein content of $15.93 \%$.

\subsection{Protein Quality}

The results of proximate analysis of the extracted dandelion leaf protein are shown in Table 4 and 5.
Table 2. Effects of $\mathrm{pH}$ and Temperature on the formation and quality of curd.

Temperature

1 st curd 1st liquor

appearance appearance Curd quality

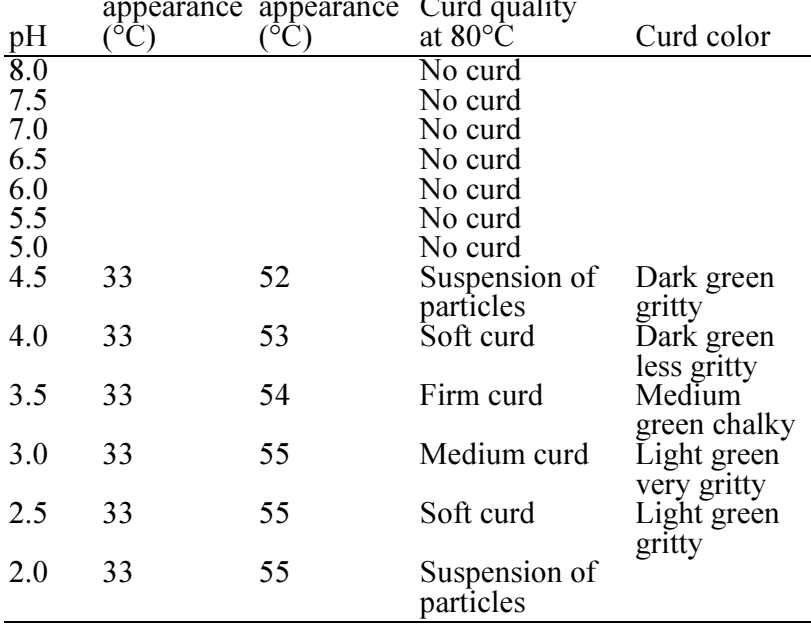

Table 3. Changes in dry matter and protein contents during the

\begin{tabular}{lccc}
\multicolumn{4}{c}{ extraction process } \\
Material & Total weight (g) & Dry matter (\%) & Protein (\%) \\
\hline Mash & 177.0 & 4.00 & 3.00 \\
Filter cake & 60.2 & 8.03 & 0.81 \\
Filtrate & 113.8 & 1.74 & 3.44 \\
Press cake & 36.6 & 16.70 & 3.87 \\
Press filtrate & 21.6 & 2.03 & 5.50 \\
Protein curd & 26.7 & 28.74 & 15.93 \\
Liquor & 106.6 & 1.13 & 1.31 \\
\hline
\end{tabular}

Table 4. Proximate analysis of dandelions leaves (wet basis) Parameter Percent

Moisture 71.26

Fat 71.26
4.91

Protein

4.91
15.93

Carbohydrate

5.90

Ash

2.00

Table 5. Composition of dandelion leaf protein (dry basis)

\begin{tabular}{lr}
\hline Content & Value \\
\hline True protein & $55.43 \%$ \\
Lipid & $17.08 \%$ \\
Starch and Fibre & $20.53 \%$ \\
Ash & $6.96 \%$ \\
\hline
\end{tabular}

The moisture, fat, carbohydrate and mineral contents of the crude protein were $71.26,4.91,5.90$ and $2.00 \%$, respectively. The protein, fat, starch and fiber and ash contents were calculated on a dry basis as shown in Table 5.

\section{DISCUSSION}

The best leaf protein can be obtained from young leaves that are initially in good condition. A crop that has been cut clean without bruising does not deteriorate quickly if kept under cool conditions. The 
protein in the cells was separated from the fibre by first blending (at moisture content of $96 \%$ and a pH of 8.25) the mash to dissolve the protein in the cell sap and then filtering the sap.

The protein dissolution depends on the $\mathrm{pH}$ and moisture content. The best results were obtained when the moisture content of the leaves was adjusted to $96 \%$. Since the isoelectric point (PI) of most proteins is at a $\mathrm{pH}$ between 3.6 and 5 (Widmann et al., 2010), the protein solubility was increased by the addition of $\mathrm{NaOH}$. Gout et al. (1992) stated that the cell sap is easily liberated at higher $\mathrm{pH}$ because the cellulose and other polysaccharides in the cell walls imbibe more water and become softer. As the cell walls swell, they free pectases which further weaken the cell walls. Obara et al. (2001) and Kinsella (1970) also stated that alkaline conditions counter act the $\mathrm{pH}$ drop that results from the rapture of acidic vacuoles during pulping which would denature the proteins and make it unavailable for extraction. Parrish et al. (1974) reported that the basic condition resulted in increasing recoveries of nutritious xanthophylls and carotene as well as better colour stability and harding properties of the final product. Pelegrine and Gasparetto (2005); Pirie (1971) and Jaenicke and Zavodszky (1990) reported that high solubility negatively affect extractability as protein denatured under extreme basic condition (pH of 11-12). Pelegrine and Gasparetto (2005) and Nagy et al. (1978) found the optimum range of $\mathrm{pH}$ for pulping to be in the range of $8-8.5$, within which the solubility of nitrogen was $70-80 \%$.

Pulping must be completed as quickly as possible to avoid sticking of protein to the fibres which render it unexractable. Once the juice is driven from the cells by pulping, it should immediately be separated from the fibre by filtration and pressing. The results showed that filtering the juice after $15 \mathrm{~min}$ produced $22 \mathrm{~mL}$ of filtrate compared to $115 \mathrm{~mL}$ when flirtation was carried out immediately after blending. Callis (1995) stated that given enough time, the protein would stick to the fibres and the leaf proteolytic enzymes would degrade the protein. The importance of rapidity was also stressed by several authors (Cheftel et al., 1992; Balny and Masson, 1993; Hayakawa et al., 1994). The results showed that the juice liberated at the higher pressure contained more protein than the juice liberated at a lower pressure.

The coagulation of the protein in the juices obtained by filtration and pressing should also be performed very quickly to minimize the action of proteolytic enzymes in the leaves in order to maintain higher protein digestability and preserve the limiting amino acids lysine and methionine. Chloroplast fragments and other organelles began to coagulate when the temperature of the juice reached $50^{\circ} \mathrm{C}$. The curd was denser and easily filtered when the juice was rapidly heated. The heat precipitated protein should be crumbled and suspended in water (10 times its weight) with the $\mathrm{pH}$ adjusted to 3.5 before filtration. This acid washing process improves the curd texture, removes some of non protein and non lipid constituents, thereby increases nitrogen and carotene contents and washes away some of the alkaloids and other toxic compounds. The protein cake contained $4.91 \%$ fatty acids, most of which were linolenic, palmitic and linoleic. The lipids found in protein contained xanthophylls and carotene both of which contain $\beta$-carotenes, the precursor of vitamin A.

The dark green brown color of the protein cake resulted from the conversion of chlorophylls to pheophytins. The protein cake at a $\mathrm{pH}$ of 4 has the keeping quality of cheese. Drying the protein cake at room temperature did not impair its nutritional quality but made it hard, dry, dark and gritty and difficult to use. The best results was obtained when the moisture content of the protein cake was maintained at $30-40 \%$, wrapped in polyethylene film and stored at $-10^{\circ} \mathrm{C}$.

Table 6 shows the protein contents of various food groups. The protein content $(4.70 \%)$ of dandelions is much higher than those of vegetable and fruits, lower than those of seeds and comparable to those of leaves except that of alfalfa. The protein content of the curd was $15.93 \%$ on wet basis (Table 4) and 55.43\% on dry basis (Table 5).

Table 6. Average protein content of various plants

\begin{tabular}{lr}
\hline Plant & Protein (\%) \\
\hline Seeds (USDA, 2005) & 17.30 \\
Peanut & 22.78 \\
Sunflower & 1.82 \\
Bean & 13.68 \\
Wheat (durum) & 23.85 \\
Cowpea & 3.27 \\
\hline Vegetables (USDA, 2005) & 2.70 \\
Artichoke & 0.91 \\
Cocksfoot & 0.65 \\
Tomato & 2.57 \\
Cucumber & 2.50 \\
Sweet potato & \\
Potato & 0.26 \\
\hline Fruits (USDA, 2005) & 1.40 \\
Apple & 0.50 \\
Apricot & 0.81 \\
Pear & 0.58 \\
Orange & 0.74 \\
Strawberry & \\
Blueberry & 16.50 \\
\hline Leaves (Ghaly and Alkoaik, 2010a) & 4.47 \\
Alfalfa & 4.35 \\
Cabbage & 4.70 \\
Tobacco & \\
\hline Dandelions (Present study) &
\end{tabular}


Amino acids are critical to life and have a many functions in metabolism. They are the building blocks of proteins, linked together in varying sequences to from a vast variety (several hundred thousands) of proteins (Chaing et al., 2007). There are 20 amino acids useful to humans, some of which are essential (Table 7) as they cannot be synthesized by the organism and must be supplied in the diet. Eight amino acids are essentials: isoleucine, lysine, methionine, phenylalanine, threonine, tryptophan, valine and lucine (Young, 1994). Cysteine (sulphur containing amino acid), tyrosine (aromatic amino acid), histidine and arginine are required by infants and growing children (Imura and Okada, 1998; WHO, 2007). The amino acids arginine, cyteine, glycine, glutamine, histidine, proline, serine and trrosine are considered conditionally essential, meaning that they are not normally required in the diet but must be supplied exogenously to specific populatipons that do not synthesize them (Furst and Stehle, 2004). Food stuff that lack essential amino acids are poor sources of protein as the body tends to deaminate the amino acids obtained, converting them into fats and carbohydrates (McGilvery, 1979).

Therefore, a balance of essential amino acids is necessary for a high degree of net protein utilization (defined as the mass ratio of amino acids converted protein: amino acids supplied). The recommended daily amounts of amino acids are shown in Table 8. Although protein is costly to produce, it is the greatest limitation to growth and good health (Young, 1994). The most disastrous consequences occur in children where protein malnutrition manifests itself in forms of two notorious diseases: Marasmus and Kwashiorkor. These disease cause loss of muscle mass, fatigue, irritability, swelling, edema, decreased immunity, pot belly, light colored thin hair, skin depigmentation, dermatitis, enlarged liver and loss of teeth (Ghaly and Alkoik, 2010a). The amino acid composition of various protein concentration prepared by acid preparation is shown in Table 9. Dandelion protein seems to be better than most seed proteins and compares favourably with animal proteins. It is similar to alfalfa protein which has been shown to be a good supplement (better than skim milk powder) to low protein diets for children. Good results were also obtained with pigs, rates and chicken (Rau et al., 1972; Vaisey et al., 1975).

Table 7. Useful amino acids (Reeds, 2000; Furst and Stehle, 2004)

\begin{tabular}{ll}
\hline $\begin{array}{l}\text { Essential } \\
\text { amino acids }\end{array}$ & $\begin{array}{l}\text { Nonessential amino } \\
\text { acids }\end{array}$ \\
\hline Isoleucine & Alanine \\
Arginine & Aspartate \\
Lysine & Cysteine \\
Methionine & Glutamate \\
Phenylalanine & Glutamine \\
Threonine & Glycine \\
Tyrosine & Proline \\
Tryptophan & Serine \\
Histidine & Asparagine \\
Valine & Selenocysteine \\
Lucine & \\
\hline
\end{tabular}

Table 8. Recommended daily amount of amino acids (WHO, 2007)

\begin{tabular}{lr}
\hline Essential & $\mathrm{mg} / \mathrm{kg}$ body \\
amino acids & weight \\
\hline Isoleucine & 20 \\
Lysine & 39 \\
Methionine & 11 \\
Cysteine & 4 \\
Phenylalanine & 15 \\
Tyrosine & 10 \\
Threonine & 15 \\
Tryptophan & 4 \\
Valine & 15 \\
\hline
\end{tabular}

- The recommended daily intake for infants (less than 1 year old) can be as high as 150 times the adult recommended daily amount but for children under 3 years is 10 times higher than the adults recommended daily amount

Table 9: Essential amino acid composition of various protein sources (Lima et al., 1965)

\begin{tabular}{|c|c|c|c|c|c|c|c|c|}
\hline \multirow{2}{*}{$\begin{array}{l}\text { Protein } \\
\text { source }\end{array}$} & \multicolumn{8}{|c|}{ Amino Acid* } \\
\hline & $\begin{array}{l}\text { Lysine } \\
\text { Tyrosine }\end{array}$ & Phenylalanine & Methionine & Threonine & Isoleucine & Lucine & Valine & \\
\hline \multicolumn{9}{|l|}{ Animal } \\
\hline Meat & 8.1 & 4.9 & 3.3 & 4.6 & 7.7 & 6.3 & 5.8 & 1.3 \\
\hline Poultry & 8.0 & 5.0 & 3.3 & 4.5 & 7.8 & 6.4 & 5.7 & 1.3 \\
\hline Egg & 7.2 & 6.3 & 4.1 & 4.3 & 4.1 & 9.2 & 4.0 & 1.5 \\
\hline \multicolumn{9}{|l|}{ Seed } \\
\hline Soybean meal & 6.4 & 4.8 & 0.6 & 3.7 & 3.5 & 6.1 & 5.0 & 1.2 \\
\hline Cotton seed meal & 4.9 & 5.4 & 1.5 & 3.7 & 3.5 & 6.1 & 5.0 & 6.1 \\
\hline Wheat gluten & 0.8 & 6.4 & 1.5 & 4.1 & 3.7 & 9.2 & 4.2 & 0.7 \\
\hline Maize endosperm & 3.6 & 4.5 & 2.1 & 3.7 & 10.5 & 3.8 & 5.7 & 0.5 \\
\hline \multicolumn{9}{|l|}{ Leaf } \\
\hline Alfalfa & 6.3 & 6.0 & 2.1 & 5.2 & 9.8 & 5.3 & 6.3 & 1.6 \\
\hline Dandelion & 6.3 & 6.0 & 3.2 & 5.1 & 9.7 & 6.1 & 6.2 & 1.4 \\
\hline
\end{tabular}

*Weight of amino acids in $100 \mathrm{~g}$ protein 
The by products of extraction are fibre and liquor. The fibre has long been recognized as an excellent animal fodder. It is more concentrated than the original material and is, therefore, easy to handle. However, the fibre has less nitrogen content than the original material and has less lignification since the plants used for leaf protein extraction are harvested at young age. Any toxic substances that would be in the original plants are washed away during extraction. The liquor can be used as a growth medium for microorganisms as it has a dry matter content of $1.13 \%$ and the nitrogen and carbohydrate contents of the dry matter are 0.48 and $4 \%$, respectively. The most important saccharides in the liquor are fructose and glucose.

\section{CONCLUSION}

The present study showed that dandelion leaves offer a good source of supplementary protein compared to other sources such as vegetable and fruits. The best leaf protein can be obtained from leaves that are initially in good conditions. Clean cutting of leaves without bruising will not deteriorate its quality when kept under cool conditions. The best results of the protein dissolution were obtained at $\mathrm{pH}$ of 8.25 and moisture content of $96 \%$ during the blending step of the extraction process. Immediate filtration after blending produced 5.2 times more juice compared to filtering after 15 min. Quick filtration and pressing will minimize the action of proteolytic enzymes in the leaves and preserve amino acids. Firm protein curd with light green chalky color.

\section{ACKNOWLEDGEMENT}

This research was supported by the National Science and Engineering Council (NSERC) of Canada.

\section{REFERENCES}

AOAC, 2005. Official Methods of Analysis. 18th Edn., Method 973.18, Association of Analytical Communities, Gaithersburg, MD.

APHA, 1990. Standard methods for examination of water and wastewater. American Public Health Association, Washington, DC.

Balny, C. and P. Masson, 1993. Effects of high pressure on proteins. Food Rev. Int., 9: 611-628. DOI: 10.1080/87559129309540980

Bhatia, J. and F. Greer, 2008. Use of soy protein-based formulas in infant feeding. Am. Acad. Pediatrics, 121: 1062-1068. DOI: 10.1542/peds.2008-0564

Callis, J., 1995. Regulation of protein degradation. Plant Cell, 7: 845-857.
Chaing, Y.S., T.I. Gelfand, A.E. Kister and I.M. Gelfand, 2007. New classification of super secondary structures of sandwich-like protein uncovers strict patterns and strand assemblage. Proteins, 68: 915-921. PMID: 17557333

Cheftel, J.C., 1992. Effect of High Hydrostatic Pressure on Food Constituents: An Overview. In: High Pressure Technology, Baffly, R. Hayashi, K. Hermans and P. Masson (Eds.). John Libby Eurotext Ltd., Montrouge, France, ISBN-13: 978-2855985121, pp 195-209.

FAO, 2002. Targeting the Rural Poor: The Role of Education and Training. 1st Edn., Food and Agriculture Organization of the United States, Rome, Italy.

Faskin, E.A., 1999. Nutrient quality of leaf protein concentrates produced from water fern (Azolla africana Desv) and duckweed (Spirodela polyrrhiza L. Schleiden). Bio. Technol., 69: 185-187. DOI: 10.1016/S0960-8524(98)00123-0

Ferrianti, M.P. and A. Fiechter, 1983. Production and Feeding of Single Cell Protein. 1st Edn., Applied Science Publications, London, UK., ISBN-10: 085334231, pp: 201.

Finke, M.D., 2002. Complete nutrient composition of commercially raised invertebrates used as food for insectivores, Biology, 21: 269-285. DOI: 10.1002/zoo.10031

Furst, P. and P. Stehle, 2004. What are the essential elements needed for the determination of amino acid requirements in humans? J. Nutr., 134: 1558S-1565S.

Ghaly, A.E. and F.N. Alkoik, 2010a. Extraction of protein from common plant leaves for use as human food. Am. J. Applied Sci., 71: 331-342. DOI: 10.3844/ajassp.2010.331.342

Ghaly, A.E. and F.N. Alkoik, 2010b. Nutritional value of the maize stalk borer and American bollworm as unconventional protein sources. Am. J. Applied Sci., 7: 1-12. DOI: 10.3844/ajassp.2010.1.12

Gout, E., R. Bligny and R. Douce, 1992. Regulation of intracellular $\mathrm{pH}$ values in higher plant cells. J. Biol. Chem., 267: 13903-13909. PMID: 1629190

Hayakawa, I. S.A.O., T. Kanno, M. Tomita and Y. Fujio, 1994. Application of high pressure for spore inactivation and protein denaturation. J. Food Sci., 59: 159-163. DOI: 10.1111/j.1365-2621.1994.tb06923.x

Heatherley, A.N., 1998. Healing plants: A medicinal guide to native North American plants and herbs. The Globe Pequot Press, Connecticut, USA, ISBN: 1-55821-508-5.

Imura, K. and A. Okada, 1998. Amino acid metabolism in pediatric patients. Nutrition, 14: 143-148. PMID: 9437700

Jaenicke, R. and P. Zavodszky, 1990. Proteins under extreme physical conditions. Fed. Eur. Bio. Soc., 268: 344-349. DOI: 10.1016/0014-5793(90)81283-T 
Kershaw, L., P. Cotterill and S. Wilkinson, 2002. Getting To Know Common Dandelions. The Alberta Native Plant Council.

Kim, S.K. and E. Mendis, 2006. Bioactive compounds from marine processing byproducts - A review. Food Res. Int., 39: 383-393. DOI: 10.1016/j.foodres.2005.10.010

Kinsella, J.E., 1970. Evaluation of plant leaf protein as a source of food protein. Chem. Ind., 17: 550-554. PMID: 5440921

Lima, I.H., T. Richardson and M.A. Stahmann, 1965. Leaf proteins as foodstuffs, Fatty acids in some leaf protein concentrates. J. Agric. Food Chem., 13: 143-145. DOI: $10.1021 / \mathrm{jf60138a013}$

Maciejewiez-Rys, J. and P. Hanczankovwski, 1990. Improvement of the nutritive value of cereals by leaf protein supplementation. J Sci. Food Agric., 50: 99-104. DOI: 10.1002/jsfa.2740500111

McGilvery, R.W., 1979. Biochemistry: A Functional Approach. 1st Edn., Saunders, pp: 862.

Mendez, M.A., 2002. Soy-based formulae and infant growth and development: A review. J. Natr., 132: 2127-2130.

Nagy, S., L. Telek, N.T. Hall and R.E. Berry, 1978. Potential food uses for protein from tropical and subtropical plant leaves. J. Agric. Food Chem., 26: 1016-1028. DOI: 10.1021/jf60219a028

Nordeide, M.B., A. Hatlgy, M. Falling, E. Lied and A. Oshaug, 1996. Nutrient composition and nutritional importance of green leaves and wild food resources in an agricultural district, Koutiala, in Southern Mali. Int. J. Food Sci. Nutr., 47: 455-468. PMID: 8933199

Obara, K., H. Kuriyama and H. Fukuda, 2001. Direct evidence of active and rapid nuclear degradation triggered by vacuole rupture during programmed cell death in Zinnia1. Am. Soc. Plant Physiol.. 125: 615-626.

Parrish, G.K., M. Kroger and J.C. Weaver, 1974. The prospects of leaf protein as a human food and a close look at alfalfa. CRC Critical Review in Food Technology, 5: 1-13.

Pelegrine, D.H.G. and C.A. Gasparetto, 2005. Whey proteins solubility as function of temperature and pH. LWT-Food Sci. Technol., 38: 77-80. DOI: 10.1016/j.lwt.2004.03.013

Pirie, N.W., 1971. Leaf Protein: Its Agronomy, Preparation, Quality and Use. 1st Edn., International Biological Programme, Oxford, ISBN-10: 0632083506, pp: 192.

Rau, B.H.S., K.V.R. Ramana and N. Singh, 1972. Studies on nutritive value of leaf proteins and some factors affecting their quality. J. Sci. Agric., 23: 233-243. DOI: 10.1002/jsfa.2740230211
Reeds, P.J., 2000. Dispensable and indispensable amino acids for humans. J. Nutr., 130: 1835-1840.

Saunders, J., T. Smith and M. Stroud, 2011. Malnutrition and undernutrition. Medicine, 39: 45-50. DOI: 10.1016/j.mpmed.2010.10.007

Shahidi, F., M. Naczk, R.B. Pegg, J. Synowiecki, 1991. Chemical composition and nutritional value of processing discards of cod (Gadus morhua). Food Chem., 42: 145-151. DOI: 10.1016/0308-8146(91)90030-R

Sikka, K.C., R. Singh, D.P. Gupta and S.K. Duggal, 1979. Comparative nutritive value of Fish Protein Concentrate (FPC) from different species of fishes. J. Agric. Food Chem., 27: 946-949. DOI: 10.1021/jf60225a032

Solbrig, O.T., 1971. The population biology of dandelions. Am. Sci., 59: 686-694.

Stewart-Wade, S.M., S. Neumann, L.L. Collins, G.J. Boland, 2002. The biology of Canadian weeds. 117. Taraxacum officinale G.H. Weber ex Wiggers. Can. J. Plant Sci., 82: 825-853.

Tangka, J.K., 2003. Analysis of the thermal energy requirements for the extraction of leaf protein concentrate from some green plants. Biosystems Eng., 86 : $473-479$. $\quad$ DOI: 10.1016/j.biosystemseng.2003.08.014

Tannenbaum, S.R. and D.I. Wang, 1975. Single-Cell Protein II. 1st Edn., The MIT Press, Boston, Massachusetts. ISBN-10: 0262200309, pp: 707.

Tilford, G.L., 1997. Edible and Medicinal Plants of the West. 1st Edn., Mountain Press, Missoula, MT. ISBN-10: 0878423591, pp: 239.

USDA., 2005. USDA National Nutrient Database for Standard Reference, Release 18. United States Department of Agriculture, Washington, DC.

Vaisey, M., L. Tassos, B. E. McDonald and C.G. Youngs, 1975. Performance of fababean and field pea protein concentrates as ground beef extenders. Can. Instit. Food Sci. Technol., 8: 74-83.

Welch, P., 2007. The dandelion: It's more than a weed. Helium, Inc.

WHO, 2002. Childhood nutrition and progress in implementing the International Code of Marketing of Breast-milk Substitutes. World Health Organization. Geneva, Switzerland.

WHO, 2007. Protein and Amino Acid Requirements in Human Nutrition. 1st Edn., World Health Organization Press, Rome, Italy, ISBN-10: 9241209356, pp: 276.

Widmann, M., P. Trodler and J. Pleiss, 2010. The isoelectric region of proteins: A systematic analysis. Plos One, 5: 1-6.

Young, V.R. 1994. Adult amino acid requirements: The case for a major revision in current recommendations. J. Nutr., 124: 1517S-1521S. PMID: 8064412 